\title{
THE POLEMIC OF GIVING DIRECT EFFECT OF WTO LAW AND DSB DECISION TO DOMESTIC LAW FOR INDIVIDUAL'S JUDICIAL PROTECTION
}

\author{
Intan Soeparna* \\ International Trade Law Department \\ Faculty of Law Universitas Airlangga, Surabaya \\ Jalan Dharmawangsa Dalam Selatan, Surabaya, East Java 60286
}

\begin{abstract}
The main objective of WTO Law is to accommodate individual's right in order to obtain better benefit of international trade. However, when a government violates WTO Law, it is therefore causing deprivation of individual right itself. Direct effect seems to be a feasible doctrine to provide a judicial protection for individual, in order to rebalance the right that is violated. Nevertheless, this doctrine is intractable to imply. This article discuss the polemic of giving direct effect of WTO Law and DSB Decision to domestic law to provide judicial protection for individual who becomes victim of WTO violation conducted by government. Keywords: WTO, DSB decision, direct effect.
\end{abstract}

\section{Intisari}

Tujuan aturan WTO adalah mengakomodasi hak individu untuk memperoleh keuntungan dalam perdagangan internasional, akan tetapi ketika pemerintahnya melanggar aturan WTO, maka akan menyebabkan pelanggaran hak. Oleh karena itu, doktrin direct effect aturan WTO dapat menjadi doktrin yang memberikan perlindungan hukum, dalam rangka menyeimbangkan hak yang dilanggar. Namun, doktrin ini sangat sulit diterapkan, oleh karena itu, artikel ini mendiskusikan polemik dalam menerapkan doktrin direct effect. Aturan WTO dan keputusan DSB agar pemerintah dapat memberikan perlindungan hukum pada individu yang menjadi korban pelanggaran aturan WTO.

Kata Kunci: WTO, badan penyelesaian sengketa, direct effect.

\section{Pokok Muatan}

A. Introduction 518

B. Discussion 518

1. Direct Effect of WTO Law and DSB Decision 518

C. Conclusion 530 


\section{A. Introduction}

World Trade Organization (hereinafter WTO) Law is not only about rights and obligations to conduct international trade among members, but also commitments from governments to their individuals. These commitments are conceivable to support individuals to achieve better income and benefit, to promote positive result of enhancing welfare, full employment and large volume of real income for individual under the WTO Law. ${ }^{1}$ Hence, the WTO Agreements directly provide wide opportunity for individuals to achieve trade benefits through their government commitments, where these commitments constitute as rights of individuals to trade freely across frontier, to enhance their benefits from international trade under the WTO Agreements, and at the end to obtain their economic rights. However, the lack of direct effect of WTO Law is preventing any individuals to rely on WTO Law in order to obtain their inviolable rights if the government violates WTO Law.

Some cases in regard with the lack of direct effect of WTO Law are hindering individuals to obtain judicial protection when their governments are violating WTO Law. For example, the lack of direct effect of the Dispute Settlement Body (hereinafter DSB) Decision and Rulings in the EU legal system ${ }^{2}$ is one of the reasons for the European Court of Justice (hereinafter ECJ) not to imply noncontractual liability in order to give compensation to Biret Company ${ }^{3}$, meanwhile, Biret was the victim of Hormone dispute between EU and The US. When
EU decided not to comply with DSB Decision in regard with Hormone ban, Biret Company were unable to sell their products to US since their products constitute as meat product consist of hormone that was banned by the EU Council Regulation. ${ }^{4}$ Similar to EU, the US law explicitly denies direct effect of WTO law, so individuals are barred off to stand before the US Court for any WTO violations that US Federal Government has conducted.

From this situation, the direct effect of WTO Law and DSB decision is debatable in terms of giving judicial protection for individuals, since most of WTO Members, such as the US and Canada, prevent private party from invoking both WTO Law and DSB decision before domestic courts, ${ }^{5}$ individuals therefore are barred from getting compensation to recover the damages suffered caused by WTO violations conducted by their governments. This article thus discuss the polemic of giving direct effect of WTO Law and DSB Decision in order to provide judicial protection for individuals who happen to be the victim of WTO Violation.

\section{B. Discussion \\ 1. Direct Effect of WTO Law and DSB Decision}

The WTO Agreements do not create direct effect to the Members, thus, it depends on WTO Members to decide whether WTO Agreements may produce direct effect within their jurisdictions, ${ }^{6}$ because in principle, international law does not interfere with the internal legal system of nations.

Richard G. Shell, "Trade Legalism and International Relations Theory: An Analysis of the World Trade Organization”, DUKE Law Journal, No. 44, 1995, pp. 830-925.

Armin Von Bogdandy, "Legal Effect of World Trade Organization Decision within European Union Law: A Contribution to the Theory of the Legal Acts of International Organizations and the Action for Damages under Article 288 (2) EC", Journal of World Trade, Vol. 39, No. 1, January 2005, pp. 45-66. Bogdandy referred that sometimes termed of direct-effect as direct applicability, invocability or elf executing nature, in sum lack of direct-effect means that an action by an individual before the ECJ cannot be based on a norm laid down in the WTO Agreements.

Case C-93/02 P, Biret International SA para. 56; Case C-94/02 P, Établissements Biret et Cie SA.

Council Directive 96/22/EC of 29 April 1996, OJ 1996 L 125/3; Council Directive 88/146/EEC of 7 March 1988, OJ 1988 L. $70 / 16$ Council Directive 81/602/EEC of 31 July 1981, OJ 1981 L 222/32.

Schaefer, Matt, “Are Private Remedies in Domestic Courts Essential for International Trade Agreements to Perform Constitutional Functions with Respect to Sub-Federal Governments?", Northwestern Journal of International Law \&Business, Vol. 17, Issue 1, Winter 1997, pp. 609-652. The main reason that Canada and the U.S. prevent private party from invoking DSB decision and rulings before domestic court is because Canada's constitutional system does not allow for direct effect of international agreements and it has chosen not to provide for private rights of action based on international trade agreements through federal implementing legislation. And the U.S. has chosen not to make recent international trade agreements "self-executing" or otherwise provide for private rights of action against either the federal or state government. Thomas Cottie and K.N. Schefer, "The Relationship between World Trade Organization Law, National Law and Regional Law", Journal of International Economic Law, Vol. 1, Issue 1, 1998, pp. 83-122. 
The reception of international legal rules is left to the domestic law of each nation. It thus depends on whether a country adopts monism or dualism theories. In monist countries, international obligations are considered a part of domestic legal system with no act of transformation required, because both international law and national law have a common underlying legal basis that derives its origin from the law of nature which binds equally the state and individuals. ${ }^{7}$ For the monist countries, international law has what is termed direct effect to their national law. Another theory is dualism theory, in dualist country, international legal obligation do not enter the domestic legal system unless an act of transformation occurs. Accordingly, the difference between international law and national law is fundamental. International law is binding base on the common will of states meanwhile national law is binding the individual within its jurisdiction. Since international law establishes a relation between its norms and the norms of the different national legal order, thus, direct effect of international law is not possible. ${ }^{8}$ Some countries are a mixture of monism and dualism. In these countries, certain international obligations will enter domestic legal system directly but some others will require an act of transformation. ${ }^{9}$

Article XVI: 4 of the WTO Agreement require Members to ensure the conformity of their laws, regulations and administrative procedures with the WTO obligations, WTO Members therefore have they own discretion to comply with the WTO obligations. The WTO Agreements do not regulate the manner in which a state may choose to put itself domestically in the position to meet its obligation.
Each member can determine in accordance with its own constitutional practice whether to give direct domestic law effect to the WTO Agreements or whether to transform, adopt or incorporate those rules into domestic law by statutes or by some other means. ${ }^{10}$ In term of compliance with the DSB decisions, Jackson has mentioned that states would be reluctant to change their domestic legislations in order to comply with DSB decision to avoid sovereignty diminution. ${ }^{11}$

The direct effect of DSB decision so far becomes major polemic in regard with the relation between the WTO and individual. Nothing in the WTO rules mention directly about this relation. However, the Panel declared in Panel Report of the US-Sections 301-310 of the Trade Act of 1974 that "under the doctrine of direct effect which has been found to exist most notably in the legal order of the EC (EU) but also in certain free trade agreements, obligations addressed to States are construed as creating legally enforceable rights and obligations for individuals. Neither the GATT nor the WTO has been so far interpreted by GATT/WTO institutions as a legal order producing direct effect. Following this approach, the GATT/WTO did not create a new legal order the subjects of which comprise both contracting parties or Members and their Nationals." 12 Accordingly, the WTO law does not oblige the Members to impose direct effect in their domestic law, but more to discretion of the Member to establish concrete parameters of the relationship between the WTO law and domestic law. ${ }^{13}$ To this end, there are two different points of views with respect to direct effect of WTO Law and DSB decision, first those who see direct effect as political

\footnotetext{
S.K. Verma, 2004, An Introduction to Public International Law, Phi Learning Ltd., Delhi/India, pp. 48 -50.

Peter Malanczuk, 1997, Akehurts's: Modern Introduction to International Law (Seventh Edition), Roudledge, London/UK, p. 63.

Thomas Cottie and K.N. Schefer, Op.cit., pp. 609-652.

John H. Jackson, 1997, The World Trading System, Law and Policy of International Economic System, Second Edition, Massachusetts Institute of Technology Press, Massachusetts/USA, pp. 79 -99.

11 John H. Jackson, “The Great 1994 Sovereignty Debate: United Stated Acceptance and Implementation of the Uruguay Round Results, Chapter 2: Constitutional Question", Columbia Journal of Transnational Law, Vol. 36, No. 7, 1997, pp. 157-188.

United States - Sections 301-310 of the Trade Act of 1974, Report of the Panel, WT/DS152/R,22 December 1999, para. 7.72.

13 Oksana Tsymbrivska, "WTO DSB Decisions in the EC Legal Order: Approach of the Community Courts", Legal Issues of Economic Integration, Vol. 37, No. 3, 2010, pp. 185-202. See also Thomas Cottier, "A Theory of Direct Effect in Global Law", in Von Bogdany, Armin, et al. (Eds.), 2002, European Integration and International Co-ordinationStudies in Transnational Economic Law in Honour of Claus-Dieter Ehlermann, Kluwer Law International - the Hague Netherland, Netherland, p. 102.
} 
decision of a state or opponent to direct effect doctrine, and second those who concern that direct effect WTO Law and DSB Decision is important.

\section{a. Argumentation about Direct Effect of WTO Law as A Political Decision}

In building the nature of direct effect of the WTO law, some authors prefer to lead their arguments that direct effect is a political decision. ${ }^{14}$ It refers to Chayes opinion, "it is natural for different laws in different circumstances bind states in different ways, thus, critique and good positive scholarship would pursue a kind of end analysis, pointing out where the level of binding force is actually less or more." $" 15$

From the EU perspective, the EU Treaties, along with the Council Decision is concluding the WTO Agreements represent the authentic political statement by the EU Member States on the issue of the WTO law. ${ }^{16}$ Antonidas opined about direct effect of WTO Law that "If the combined interpretation of the case law, the legislative activity and the institutional practice means that the EU legal order is a dualist that one for the purposes is the application of the WTO law, then so be it. Following from this, unless the EU transforms the WTO law into the EU legal system by means of transposition into its own legal instruments, the WTO law cannot have direct effect. This means that the EU chooses WTO law as a second best set of rules. In its internal policy making, it uses WTO law as a benchmark and accepts its primacy in its commercial policy instruments. It therefore tries to interpret legislation consistently with the WTO Agreements." ${ }^{17}$ In fact, the ECJ needs to support the supremacy of EU Law, ${ }^{18}$ thus the recognition of direct effect of the WTO law would deprive the ECJ from the authority to uphold the supremacy of the EU Law. ${ }^{19}$ Bogdandy also revealed that if the WTO law has direct effect, it will have a constitutional function for the EU legislator, because direct effect of WTO law is the most relevant legal feature to have alleged constitutional function to stipulate the supremacy of international treaties over EU legislation. The ECJ does not exclude any effect of WTO law, but it denies direct effect when it comes to force the legislative institutions of the Union to comply with the WTO law. ${ }^{20}$ The denial of direct effect of the WTO law therefore is rather the political exception for the EU approach to international law. ${ }^{21}$ Trachtman emphasized that the direct effect of WTO Law as political bargain between EU and other WTO Members. The ECJ has generally declined direct effect of GATT obligations because other states do not accord direct effect thereto. It would create a bargaining disparity which would have to be accorded if the US denied direct effect to these obligations while the EU

14 Joel. P. Trachtman, "Bananas, Direct Effect and Compliance”, European Journal of International Law, Vol. 10, No. 4, 1999, p. 664. Trachtman emphasized that "the grant of direct-effect to a legal rule is a political decision, as the EC and the U.S. have recognized in different ways".

15 A. Chayes and A.H. Chayes, 1998, The New Sovereignty: Compliance with International Regulatory Agreements, Harvard University Press, Cambridge MA/USA, pp. 17-22.

16 Pieter J. Kuijper, "The Conclusion and Implementation of the Uruguay Round Results by the European Community", European Journal of International Law, Vol. 6, No. 1, 1995, pp. 222-244.

17 Antonis Antoniadis, "The European Union and WTO Law: A Nexus of Reactive, Coactive and Proactive Approaches", World Trade Review, Vol. 6, No. 1, 2007, pp. 45- 87, p. 86. See also Piet Eeckhout, "The Domestic Legal Status of the WTO Agreement: Interconnecting Legal Systems", Common Market Law Review, Vol. 34, Issue No. 1, 1997, pp. 11-29.

18 Christian Timmermans, "The EU and Public International Law", European Foreign Affairs Review, Vol. 4, No. 2, 1999 , p. 181.

9 Antonis Antoniadis, Op.cit., pp. 86-87.

20 Armin Von Bogdandy, "Pluralism, Direct Effect, and the Ultimate Say: On the Relationship between International and Domestic Constitutional Law", International Journal of Constitutional Law (I.CON), Vol. 6, No. 3\&4, 2008, pp. 397-413.

21 J.H.H. Weiler, 1999, The Constitution of Europe, Cambridge University Press, UK, pp. 295-298. See also Jan Klabbers, "International Law in Community Law: The Law and Politics of Direct Effect”, in Eeckhout, Piet, et al., 2001 - 2002, 21 Year Book European Law, Oxford University Press, Oxford/UK, pp. 274-275. 
accorded direct effect. Thus according to this interpretation, the ECJ simply is upholding political bargain, as in Portugal vs. Council Case the ECJ suggested that the absence of reciprocity as to direct effect would lead to an imbalance of the WTO obligations between EU and its trading counterparts in WTO. ${ }^{22}$

Hence, the direct effect of WTO Law also deprives the freedom of political institutions. There are two aspects of the freedom of political institutions, first is the external aspect, where the grant of direct effect is destined to weaken the negotiating strength of the institutions within the WTO in relation to the most important trading partners. Second is the internal aspect, the shift of the institutional balance in external trade matters from the Council and the Commission to the Court. The direct effect of the DSB Decision would also have the consequence that any EU legislative measure could be challenged before the court as the WTO incompatible. ${ }^{23}$

\section{b. Opponent Argument regarding Direct Effect of DSB Decision \\ 1) Direct effect of DSB Decision from the EU Standpoint}

Direct effect doctrine has appeared in international law under several terms ranging from direct applicability and self-executing provision to direct effect. ${ }^{24} \mathrm{EU}$ Member States refer to classic definition of direct effect that the objective of direct effect is a legal provision granting rights to individual which must be upheld to national court. ${ }^{25}$ The European Courts have authority to establish whether a DSB Decision has direct effect or not in their cases, such in Biret Case, Chiquita Case, the Case of Van Parys and FIAMM Case, but none from the judgment of those cases entail justification of direct effect of DSB Decision, except in Biret case, when the ECJ considered that DSB Decision in Hormone Case was inescapably and directly linked to the plea alleging of the infringement of SPS Agreement, the ECJ therefore criticized the General Court (hereinafter GC) for not having explicitly addressed whether the DSB decisions could have direct effect and provide grounds for a review of $\mathrm{EU}$ Institutions acts. ${ }^{26}$

Nevertheless, before the establishment of the WTO, the ECJ had experience to deny the direct effect of GATT 1947. The ECJ argued that the GATT had to be conceived as a trade/ diplomatic tool, rather than a judicial one, and the flexible and imprecise agreement is incapable of conferring rights that citizens can invoke in domestic courts to challenge the lawfulness of a EU act, also preclude the court from taking provisions of

22 Joel P. Trachtman, "Bananas, Direct Effect and Compliance", European Journal of International Law, Vol. 10, No. 4, 1999, p. 664. Trachtman emphasized that "the grant of direct-effect to a legal rule is a political decision, as the EC and the U.S. have recognized in different ways". See also Peter Stoll Tobias and Frank Schorkopf, 2006, Max Planck Commentaries on the World Trade Law, Max Planck Institute for Comparative Law and International Law, Martinus Nihoff, Leiden/Netherland, p. 42. The provision of WTO Law does not deem to be suitable for direct application, as it considers the WTO rules to be subject to reciprocity and negotiation between the Members of WTO. In contrary, Petersmann argues that denial of direct-effect on the ground of lack of reciprocity is unjustified since almost international agreements are based on some kind of reciprocity. See also Petersman, Ernst-Urlich, "Application of GATT by the Court of Justice of the European Communities", Common Market Law Review, Vol. 20, Issue 3, 1983, p. 426.

23 John H. Jackson, Op.cit., pp. 315-319. Jackson mentioned that "direct effect would considerably strengthen the role the judiciary to the detriment of other power and thereby adversely affect the institutional balance as established in the national constitution. Beyond that, a directly effective international treaty superior to ordinary domestic legislation may be subversive to the idea of democratic representation."

24 Jan Klabbers, "International Law in Community Law: The Law and Politics of Direct Effect", in Piet Eeckhout, et al., 2001-2002, in 21 Year Book European Law, Oxford University Press, Oxford/UK, p. 272.

25 Eileen Denza, 2002, The Intergovernmental Pillars of the European Union, Oxford University Press, Oxford/UK, p. 14.

26 See Case C-93/02 P, Biret International SA para. 56; Case C-94/02 P, ÉtablissementsBiretetCie SA para. 59. 
GATT into consideration to assess the lawfulness of a regulation in an action brought by a Member State. ${ }^{27}$ The ECJ still implies this concept after the 1994 of WTO establishment, although in Biret Case, the court introduced an innovative conceptual distinction between the direct effect of WTO Law and reliance on the DSB Decision, thus, individual potentially could be permitted to invoke a DSB Decision condemning the $\mathrm{EU}$ as a basis for claiming damage before the ECJ, pursuant to Article 288 EC Treaty (340 TFEU) ${ }^{28}$ But the ECJ rejected to give compensation to Biret, because Biret did not suffer any damages after the expiration of the reasonable period of time to comply with the DSB Decision. The reason was that Biret went out of business in 1995, while the fifteen-month implementation period ended in May 1999. The ECJ therefore considered that there was no causal link between the damage and the act of EU Institutions. ${ }^{29}$ And the most prominent argument from ECJ is that the court mostly relied on concern over the lack of reciprocity principle as a powerful reason to reject the direct effect of the WTO law. ${ }^{30}$
The ECJ added in their judgment that evaluating the invocability of a DSB Decision is a conceptually separate problem from the implementation of direct effect of DSB decision. The ECJ also argued that giving possibility for private party to claim compensation for damage does not amount to the recognition of direct effect. ${ }^{31}$ Thus, the ECJ recognized the argument relating to the legal effects of DSB decision is autonomous from that pertaining to the direct effect of WTO Law. Although, it confirms that the previous judgment did not tackle the issue of direct effect of the DSB. ${ }^{32}$

In Chiquita case, the Court was also giving argument in regard with non-direct effect of DSB decision, mentioned that "since the WTO Law has no direct effect, an action for noncontractual liability directly based on an infringement of WTO Law would be bound to fail". ${ }^{33}$ However, similar to Biret case, in Chiquita case, the Court considered "the DSU does not establish a mechanism for judicial resolution of international dispute by means of decision with binding effect comparable with those of a court decision in the internal legal system of

27 Case C-280/93, Federal Republic of Germany v. Council of the European Union, [1994] ECR I-4973, para. 5073. See also Case C-21/72, International Fruit Co. v. Produktschap voor Groenten en Fruit, (1972) ECR 1219.

28 Anne Thies, 2013, International Trade Dispute and EU Liability, Cambridge University Press, Cambridge/UK, (Kindle Cloud Reader), Location 317.

29 Case T-174/00, Biret International SA v. Council para.57 (Jan. 11, 2002), available at http://europa.eu.int, Case T-210/00,ÉtablissementsBiret et Cie SA v. Council para. 64 (Jan. 11, 2002), available at http://europa.eu.int, last visited December 2012. The ECJ rejected the appeal of Biret Company because according to the court a right to recover damages suffered before the end of the deadline would render ineffective the grant of a reasonable time period for compliance with the DSB ruling.

30 Case C-149/96, Portuguese Republic v. Council, 1999 E.C.R. I-8395, The ECJ argument in regard with the reciprocity is merely realpolitik argument rather than legal argument. The EU has to maintain the balance between its various institution and members, and minimizing possible negative implications on its legal order from evolving system like GATT (or WTO today).

31 Mohamad F.A. Nsour, 2010, Rethinking the World Trade Order towards A Better Legal Understanding of the Role of Regionalism in the Multilateral Trade Regime, Sideston Press, Leiden/the Netherland, p. 194. Nsour opined that "Biret case can be considered a modest but promising start for creating a better legal nexus between a key RTA like the EU and the Multilateral system."

32 Fabrizio Di Gianni and Renato Antonini, "DSB Decisions and Direct Effect of WTO Law: Should the EC Courts be more Flexible when the Flexibility of the WTO System has Come to an End?", Journal of World Trade, Vol. 40, No. 4, 2006, pp. 777-793.

33 Ibid, p. 784. See Case T-19/01, Chiquita v. Commission, Judgment of 3 February 2005. 
the Member States." 34

In Van Parys case, the ECJ observed that "obliging courts to set aside rules of domestic law when they are found to be incompatible with WTO rules would hinder the possibility of reaching a negotiated solution. Moreover, requiring the EU Courts to review the legality of EU measures in the light of the WTO rules, on the sole ground that the time-limit for implementation of the DSB decision has expired, could undermined the EU position in trying to reach a mutually acceptable and WTO conforming solution to the dispute." ${ }^{35}$ In the Case of Van Parys, the ECJ concluded that Van Parys did not have the possibility to invoke before a national court, the incompatibility of EU measures with certain WTO rules, even though the DSB had declared the EU legislation to be incompatible with those rules.

In FIAMM and Fedon case, the ECJ made another statement regarding direct effect of DSB Decision, since those companies requested the Court to make distinction between the direct effect of provision of WTO Agreements which imposed substantive obligations, and the direct effect of a ruling of the DSB. Nevertheless, according to the Court, its case law shows that such distinction cannot be made. "DSB decision, which has no object other than to rule on whether a WTO member's conduct is consistent with the obligations entered into by it within the context of the WTO, cannot in principle be fundamentally distinguished from the substantive rules which convey such obligations and by reference to which such a review is carried out, at least when it is a question of determining whether or not an infringement of those rules or that decision can be relied upon before the EU Courts for the purpose of reviewing the legality of the conduct of the EU Institutions." 36 Hence, in this case the Court put aside again the direct effect of DSB decision.

2) Direct Effect of DSB Decision from the US Standpoint

From the US perspective, WTO supremacy is excluded as an option for the US legal system. A subsequent federal statute always overrides a prior self-executing or having direct effect international agreement. Although, the decision of DSB in principle entails an obligation, it cannot be self-executing or directly applicable in the strict meaning of the words, thus, it cannot give rights for individuals.

However, there are some argu-

34 Ibid. See also Adam Cygan, "The European Court of Justice and External Relations: Internationalist Objectives or Integrationist Policy”, in Jen Uwe Wunderlich, et al., 2011, The European Union and Global Governance: A Handbook, Routledge International Handbook, UK, p. 112. The Court's case law recognizes the importance of the Community International Trade obligations, but the policy of the judgment is that direct effect will only be permitted when WTO decision are themselves binding on all members.

35 Case C-377/02 Van Parys v BelgischeInterventie- en Restitutiebureau, Judgment of 1 March 2005. See Patricia Egli, "Le'on Van Parys NV v. BelgischInterventie- en Restitutiebureau: ECJ Judgment on Effect of WTO Agreements and Dispute Settlement Decisions in EC Law", in Daniel Bodansky, "International Decisions", American Journal of International Law, Vol. 100, No. 2, 2006, pp. 449- 454.

36 Joined Cases C--120/06 P and 121/06 P, FabbricaltalianaAccumulatoriMotocarriMontecchioSpA (FIAMM) and Others v. Council and Commission and Giorgio Fedon\&FigliSpA and Others v. Council and Commission, 2008, ECR I-6513.

37 John J. Barceló III, "The Paradox of Excluding WTO Direct and Indirect Effect in U.S. Law, in Tulane European and Civil Law Forum", Dedicated to Preserving and Advancing the Civilian Tradition and to Strengthening Louisiana's Links with Europe: Companions and Crossroads: Essays in Honor of Shael Herman, Tulane School of Law Journal, 2006, p. 147-167. In the U.S. international agreements are given indirect effect based on the Charming Betsy canon of interpretation of federal statutes that first articulated in the early Supreme Court Case of Murray v. the Charming Betsy. See also Jackson, John J., Davey, William J., and Sykes, Alan O., 2002, Legal Problems of International Economic Relations: Cases, Materials, and Text on the National and International Regulation of Transnational Economic Relations, West Publishing Company, NY/USA, p. 244. 
ments leading to the concept indirect effect of DSB Decision in the US legal system. ${ }^{37}$ Although the US has declared that reports issued by Panel or the Appellate Body under the WTO Dispute Settlement Understanding (hereinafter DSU) have no binding effect under the law of the US and do not represent an expression of the US foreign or trade policy, but the US courts can engage in indirect application of DSB Decision. For example, in order to apply a DSB Decision that found a particular US measure WTOinconsistent in a domestic case which is involving a similar but not identical with the US measure, the court would be applying the DSB Decision indirectly. Furthermore, it has to be pointed out that the inconsistency of a US measure or provision with the WTO law can concern federal statutes or regulations or practice of executive agencies. It will emerge indirect effect by drawing the consequences from the inconsistency of a US interpretation of a WTO law provision in a federal status, the regulation or practice with an adopted DSB Decision against the US relating to it where the WTO inconsistency refers to the ambiguous legislative measure. The US Courts therefore could infer authority from DSB Decisions. ${ }^{38}$ The indirect effect doctrine has surfaced most prominent in the US in connection with trade remedy law, such as antidumping, countervailing duty, and safeguards (or escape clause) law. For example in the Allegheny Case $^{39}$, a case regarding countervailing duties, the court referred to Charming Betsy doctrine ${ }^{40}$ when considering the effects of a DSB Decision. In this settled case, the court had to judge on a methodology followed by Department of Commerce to calculate a countervailing duty to be applied against a subsidized company. In order to comply with the recommendations of DSB, Department ofCommerce changed the methodology to calculate the countervailing duty according, and adopted new decision, although it would have applied only to future investigations. Accordingly, the judgment of the Court did not take new decision, since it remained consistent with the interpretation of DSB Decision. ${ }^{41}$

Principally, the US Courts do not give direct effect, and if there is indirect effect to WTO Law within the US legal system, it is severely circumscribed and subordinated to political process, because it will derive from political pressure from import competing interest. The Executive Branch, in favors of WTO compliance, is certainly capable to this political pressure. However, legitimizing political pressure can achieve a kind of optimality by maximizing political

\footnotetext{
Giacomi Gattinara, “The Relevance of WTO Dispute Settlement Decision in the U.S. Legal Order", Legal Issues of economic Integration, Vol. 36, No. 4, 2000, pp. 285-312.

39 Allegheny Ludlum Corp vs. U.S., 367 F. 3d 1339 (Fed. Cir. 2004).

40 Case Murray vs. Schooner Charming Betsy, 2 Cranch 64, US 64, 2L.Ed. 208 (1804). See also C.A. Bradley, "The Charming Betsy Canon and Separation of Powers: Rethinking of the Interpretative Role of International Law”, Georgetown Law Journal, Vol. 86, No. 7, 1998 , p. 491. Charming Betsy Doctrine remain the doctrine that is used by the national court, in case a possible conflict between a domestic provision and an international obligation, the national court shall look first of all at the content of the national rule and see if there is scope for interpretative. In fact, in such a case, an unambiguous statute will definitely prevail over a conflicting international obligation.

41 The basis claim of Allegheny Ludlum Corp. is the DSB Decision on United States - Countervailing Measures Concerning Certain Products from the European Communities, WT/DS212/AB/R, 9 December 2002.
} 
support for open trade by supporting open market initiatives whenever the costs to import competing interests are not excessive. Thus, political leaders who anticipate pressure to aid injured industries may be more willing to make trade concessions across the board if they know that they can respond the interest party by changing the policy. ${ }^{42}$ The use of Charming Betsy doctrine is more a political responsive in a way to achieve indirect effect rule for the WTO, but it is not a choice with a forgone conclusion for an open trading system. It is likely if direct effect is granted, it would pose a big threat to trade remedy law in the US legal system. Since domestic application of trade remedy rules through agency action and deferential court review still holds open avenues for the exertion of political pressures, especially through the agencies. Panel and Appellate Body decisions at the WTO level would be insulated from such influence. Hence, using direct effect principle for DSB Decision will curtail protectionism that clearly some import competing industries would not want those decisions to have direct effect. ${ }^{43}$

The status of DSB decision in the US legal system has received significantly less consideration ${ }^{44}$, because there is not necessary to give direct effect in order to solve the problem of non-compliance of DSB
Decision, since domestic litigation might serve as a substitute for, rather than a complement to. And in general, if the reason to give direct effect of DSB Decision in domestic courts will enhance the certainty and predictability of the WTO Law, it would likely produces inconsistent judicial interpretations in over 157 WTO Members States, because the frequent disagreements are inevitable when hundreds of domestic courts are all independently empowered to identify the best readings of ambiguous treaty text and dispute resolution reports..$^{45}$

\section{3) The Importance of Giving Direct Effect of WTO Law and DSB Decision to Domestic} Law

Unlike those who opponents to direct effect of WTO Law, there are some arguments in regard with the importance of giving direct effect of the WTO law and DSB Decision to domestic law. ${ }^{46}$ It mostly relates to the rights of individual to invoke treaty provision before the domestic court. Tumlir is a pioneer in supporting direct effect of economic treaty in general from individual standpoint. He argued that "one can imagine the international economy policy commitments of government to be undertaken in the form of self-executing or directly effective treaty provisions, creating immediate private rights enforceable against one's own government. These

42 Alan O. Sykes, "The Persistent Puzzle of Safeguards: Lessons from the Steel Dispute", Journal of International Economic Law, Vol. 7, Issue 1, 2004, pp. 523-564.

43 Daniel Tarullo, "The Hidden Costs of Dispute Settlement: WTO Review of Domestic Anti-Dumping Decisions", Law and Policy in International Business, Vol. 34, No. 1, 2002, pp. 109-180.

44 Arwel Davies, "Connecting or Compartmentalizing the WTO and United States Legal Systems? The Role of the Charming Betsy Canon", Journal of International Economic Law, Vol. 10, Issue 1, 2007, pp. 117-149.

45 Jeffrey L. Dunoff, "Less than Zero: the Effect of Giving Domestic Effect to WTO Law", Loyola University Chicago International Law Review, Vol. 6, Issue 1, 2008-2009, pp. 279 -310.

46 Thomas Cottier, 2007, The Challenge of WTO Law: Collected Essay, Cameron May, London/UK, p. 2. 
rights would be enforceable in national courts only with no sacrifice of legal sovereignty." 47 Tumlir emphasized the notion of direct effect is 'granting right to individual for judicial protection derives from the International Treaty'. Moreover, using the judicial protection would also be a safeguard for individuals who suffered damage from protectionist national policy. For example, the reason for the claim of Biret and FIAMM was because the EU deliberately maintained WTO inconsistent measures on behalf to protect its national policy. Hence, if the WTO Law was granted direct effect, individual could invoke its provisions before domestic courts and it would be a form of judicial protection available to those citizen harmed by protectionist national policy.

The idea of giving direct effect in order to grant the rights of individual is also posited by Moser. He argued that "the domestic foreign trade laws of most states circumscribed the discretionary trade policy powers of governments only in vague terms, and protection of individual rights and judicial review are often less developed in the trade policy than in other fields of domestic economic regulation. Trade restrictions can also be used as a mean of escaping the legal disciplines of domestic economic law. It causes harmful 'external effect' not only to domestic consumers and export industries, but also to foreign trading nations." Moser emphasized that an open international economic order is not dependent on international enforcement, but it will emerge if national governments protect certain basic rights for individual and only if international contracts are enforced in the national courts. ${ }^{48}$

In terms of giving direct effect to WTO Law, Van den Bossche also underlined the main argument in favor of the idea of granting direct effect is the argument of judicial protection for individual. If individuals could rely on the provisions of the WTO Agreements, their rights to trade freely with foreigners would be judicially protected and enforced. ${ }^{49}$ Similar to arguments above, Kuilwijk argued that "in the EU perspective, the EU and those Member States have committed themselves at the international level to opt only for the first best policy instrument. These policy instruments provide for the quickest and least harmful route to economic welfare. Policy instruments which are not compatible with GATT law must be considered, per definition, manifestly erroneous. The Court would thereby also better to protect the individual rights of EU traders." ${ }^{50}$

Another argument is the effectiveness of WTO Agreements. By

\footnotetext{
47 Jan Tumlir, "International Economic Order and Democratic Constitutionalism", ORDO -Jahrbuch Fur die Ordnung von Wirtschaft und Gesselschaft, Vol. 34, 1983, pp. 71-83. See also J.H.J. Bourgois, "The Uruguay Round of GATT: Some General Comments from an EC Standpoint", in N. Emilou and D. O'Keefe, 1996, The European Union and World Trade Law After the GATT Uruguay Round, John Wiley \& Sons, New York/USA, pp. 86-90. Bourgois argued "what is in the end the use of making law, also international law, designed to protect private parties, if these private parties cannot rely on it?".

4 Peter Moser, 1990, The Political Economy of the GATT, Verlag Ruegger, Switzerland, pp. 141-150.

49 Peter Van den Bossche, 2005, The Law and Policy of the World Trade Organization; Text, Cases and Materials, Cambridge University Press, Cambridge/UK, pp. 65-67.

50 Kees Jan Kuilwijk, 1996, The European Court of Justice and the GATT Dilemma: Public Interest Versus Individual Right, Nexes Edition Academic Publisher, The Netherland, p. 257.
} 
giving direct effect, domestic court is able to review the implementation of WTO Agreements by legislative body. It should give value to the effectiveness of WTO Agreements. Brand argued that principally international law would be effectively enhanced through the observance and application in domestic law. But if international law has no real effect on people's lives, then its value is substantially diminished. And if international law has real effect on people's lives, but those people have no access to its application, this also diminishes its value. The concept of direct effect of international economic law therefore carries great significance in the development of the relationship between the individual and international law. Governmental institutions cannot ignore the importance of this concept to the developing global legal framework. ${ }^{51}$

In the European Courts, some opinions are also relating to the protection of individual rights under the WTO Law, for example Advocate General Alber in Biret case who emphasized that the WTO norms have as their objects to protect individual, thus it should be directly applicable. Alber also proposed ECJ to declare that WTO Law has direct effect in the framework of damages action, because the fact that the WTO infringed are embodied in DSB Decision would entitle private parties to invoke them once the reasonable period of compliance has expired. ${ }^{52}$ Moreover, AG Alber considered that granting binding effect to DSB Decision will not weaken the trading position of the EU, as one of the WTO Members cannot decide to maintain rules contrary to WTO Law. Alemano commented that, "allowing individuals to rely on DSB Decision and Rulings to seek compensation for damages deriving from noncompliance may strike a better balance between the interests of member states and their private business operators, and the invocability of DSB rulings could improve the relationship between private operators and the multilateral trading system without modifying its flexible nature. ${ }^{53} \mathrm{He}$ referred to the argument of AG Alber in Biret Case who argued that, "the recognition of the direct effect of Panel or/and Appellate Body rulings would not reduce the margin of discretion that WTO Members enjoy in the implementation process, because once the DSB has issued a Decision, there is no more room for negotiation, the DSB recommendations must be implemented." ${ }^{54}$ His opinion is strengthening the opinion of $\mathrm{AG}$ Maduro in FIAMM case who underlined that "there can be still a room for application of the WTO rules by the courts only in so far as that would not affect the scope for negotiations for the WTO disputant parties, even in the event of the dispute itself. It is because political freedom to negotiate

51 Ronal A. Brand, "Direct Effect of International Economic Law in the United States and the European Union", Northwestern Journal of International Law \& Business, Vol. 17, Issue 1, Winter 1997, pp. 557 - 608.

52 Opinion of Advocate General Siegbert Alber in Cases C-93/02 P and C-94/02 P, Biret International SA and Etablissements Biret et Cie. SA v. Council of the European Union, in EU Press Release, CJE/03/39, 15 May 2003, p. 120.

53 Alberto Alemanno, "Judicial Enforcement of the WTO Hormones Ruling Within the European Community: Toward EC Liability for the NonImplementation of WTO Dispute Settlement Decisions?", Harvard International Law Journal, Vol. 45, Issue 2, 2004 , p. 560.

54 See C-93/02 P, Biret International SA para. 63-64; Case C-94/02 P, Établissements Biret et Cie SA para. 66-6. 
continues to exist if the reasonable period of time for implementation of the DSB Decision had not yet expired. But, FIAMM and Fedon have fair point in seeking compensation due to incompliance with the DSB Decision, since the reasonable period that the EU had been allowed to comply with the DSB Decision had expire on 1 January 1999." ${ }^{55}$ However, the European Courts declined to consider rights of individual to invoke a DSB Decision in order to set aside domestic legislation. ${ }^{56}$

Cottier argued that the court should be able to protect individuals from denial of justice due to violation of WTO Agreements. Because Members of WTO are bound by dispute settlement decision as a matter of international law, the domestic court and domestic authority therefore should take into account the legalization of the DSB Decision and its guarantees of due process and fairness as a matter of domestic law. In principle, DSB Decision should be implemented and the court should refrain from applying domestic rules found to be inconsistent with DSB Decision. ${ }^{57}$ Cottier refers to the idea of Tumlir regarding the importance of granting right for individual to invoke treaty provision before domestic court. Tumlir emphasized that direct effect of trade treaties as a weapon against inherently protectionist tendencies in domestic law systems. He suggested granting individuals the right to invoke treaty provision before their domestic courts in order to protect them from protectionism of national policy that put in to effect by other national interest group. ${ }^{58}$

The major point from arguments above is that direct effect of WTO Law and DSB Decision is important in order to give certain judicial protection for individual in terms of violation of WTO Law. Direct effect of WTO Law is also a measure for the effectiveness of international trade law where the effectiveness depends on whether international trade rules are complied with by governments and whether compliance with the norms actually has a constraining influence on protectionist measures and thereby furthers the goals of the WTO rules. However, giving direct effect of the WTO Law is not simple; many contradictory arguments appear as polemic for individual to obtain judicial protection caused by the violation of WTO Law. In recent research some scholars such as Pettersmann, Cottier and Trachtman even tried to penetrate the idea of constitutionalization of the WTO Agreements, in order to build direct effect doctrine in a way to give deepen reason for what the WTO Agreement is purposed to be.

\section{4) Building Direct Effect of WTO \\ Law from Constitutional Approach of WTO}

Some arguments are leading to the constitutional approach to build direct effect of WTO Law where

Opinion of Advocate General Poiares Maduro in Joined Cases C--120/06 P and 121/06 P, Fabbricaltaliana Accumulatori Motocarri Montecchio SpA (FIAMM) and Others v. Council and Commission and Giorgio Fedon\&FigliSpA and Others v. Council and Commission [2008] ECR I--6513 delivered on 20 February 2008.

56 See Biret International SA Case, para. 59.

57 Thomas Cottier and Mathias Oesch, "WTO Law, Precedents, and Legal Change”, Turku Law Journal, Vol. 3, No. 1, 2001, pp. 27-41.

58 Thomas Cottier and N.K. Scheffer, "The Relationship between World Trade Organization Law, National Law, and Regional Law", Journal of International Economic Law, Vol. 1, Issue. 1, 1998, pp. 83-122. 
central implication on constitutional approach to the WTO Agreement is constitutional norms. Constitutional norms are rights (individual rights) and therefore the WTO system should evolve to a point where individuals rather than states can rely on directly enforceable of WTO law or it is called "direct effect". ${ }^{59}$ This constitutional norm of the WTO law is articulated by Petersmann who sets up the idea about right-based constitutionalization. He argued that the WTO Agreements should be read as constitutional instrument. Based on this understanding, the WTO Agreements do not only employ formal techniques as constitutional method, but also includes various substantive principles as constitutional principles. These constitutional methods and constitutional principle are characteristic of constitutionalism. WTO law can thus be conceived a part of multilevel constitutional framework in multilevel trade governance. Moreover, the WTO constitution complements with national constitutions of national governments. ${ }^{60}$ The WTO Agreements may also consists not only rights and obligations among states, but also governmental obligations to protect private rights, such as right to trade $\mathrm{e}^{61}$ and private right to judicial remedies. ${ }^{62}$ From this point of view, Petersmann posited that a concept of rightbased constitutions is a democratic governance powers restrained by comprehensive guarantees of fundamental rights. ${ }^{63}$ Furthermore, WTO constitution can also help to set up multilevel restraint and to prevent human rights of citizen from being abused by government power. The right-based constitutionalization in the WTO is aimed to balance the state centered concept built in the establishment of the WTO, because like other international agreement, the WTO is perceived as intergovernmental rights and obligations among states to protect freedom and non-discrimination in international economic relations without corresponding to individual rights. ${ }^{64}$ The international trade relations thus need a value balance

59 Robert Howse and Kalypso Nicolaidis, “Enhancing WTO Legitimacy Constitutionalization or Global Subsidiarity?”, in Robert Howse, 2007, The WTO System: Law and Legitimacy, Cameron May Ltd., London/UK, pp. 247 - 268. However, Howse criticized that, "constitutionalism is viewed as the mean of placing law, or the true of law, above politics. WTO constitutionalism is achieving such a result with respect to economic rights - limits that are attributed to the capture of domestic politics. In short, a constitutitionalized WTO attempts to place economic freedom above politics. For us, however, just the reverse is necessary to address the legitimacy crisis of the multilateral trading order, more politics needed, not less".

60 Ernst-Urlich P. Peterslann, "Multilevel Trade Governance in the WTO Requires Multilevel Constitutionalism”, in C. Joergens and Ernst Urlich Petersmann, 2006, Constitutionalism, Multilevel Trade Governance and Social Regulation, Hart Publising, Oxford/UK, pp. 32-33.

61 Right to trade is recognized as fundamental rights according to ECJ in the Case 240/83, ADBHU, 1985, ECR 531, p. 548.

62 Deborah Z. Cass, "China and the 'Constitutionalization' of International Trade Law", in Deborah Z. Cass, et al., 2003, China and the World Trading System: Entering the New Millennium, Cambridge University Press, Cambridge/UK, p. 50. Right of private to judicial remedy is one of the examples for the effect of constitutionalization of WTO upon China, especially in the area of intellectual property rights.

63 Ernst Urlich Petersmann, "How to Constitutionalize International Law and Foreign Policy for the Benefit of Civil Society?", Michigan Journal of International Law, Vol. 20, No. 1, 1998, pp. 1-30. Petersmann adopted concept of a constitutions that can be used in a broad sense for the basic legal framework of a given human community which defines the common rules for ensuring equal freedoms under the rules of law and sets up institutions and decision-making processes for the making administration, and judicial enforcement of rules. In contrary to this argument, Dunnof argued that "The WTO treaties do not enshrine a series of fundamental rights, much less a fundamental of freedom of trade, the Uruguay Round Agreement is silent about this". See Dunnof, Jeffrey L., "The Politics of International Constitutions: the Curious Case of the World Trade Organization", in Jeffrey L. Dunnof and Joel P. Trachtmann (Eds.), 2009, Ruling the World?: Constitutionalism, International Law, and Global Governance, Cambridge University Press, NY/USA, p. 189.

64 Ernst Urlich Petersmann, "Constitutionalism and WTO: from a State - Centered Approach towards a Human Rights Approach in International Economic", in Kennedy, Daniel L.M. and Southwick, James D., 2002, The Political Economy of International Trade Law: Essays in Honor of Robert E. Hudec, Cambridge University Press, Cambridge/UK, pp. 32-67. Petersmann argued that "from a democratic perspective, rights of states are merely derivative of the rights of their citizens; sovereignty must be understood not as "freedom of governments" but as "popular sovereignty" constitutionally limited by human rights and democratic principles". 
between state centered concept and right-based concept where the prominent value of international trade is correctly delivered in terms of individual benefits from global trading. The value balance is to mitigate the arbitrary power of government, as Petersmann noticed that government powers risk being abused for distorting market competition and for redistributing income for the benefit of powerful group interests. ${ }^{65}$ The constitutionalization of WTO requires the subjection of WTO members to the rules and obligation of WTO which can be realized along the route of direct effect or direct applicability of WTO rules by national court. ${ }^{66}$

Cottier is one of the WTO constitutionalists who purposed a classic constitutionalism where direct effect of suitable provisions of WTO law would enable the domesticjudiciary to check the Member's executives and legislative body who have unlimited discretion in applying WTO rules. It means that constitutionalism of WTO is to control political power in order to safeguard the autonomy of the individual. The constitutional approach to the judiciary also permits us to appraise the WTO dispute settlement institutions and the national courts as forming one multilevel judiciary. ${ }^{67}$ It is coherence with the concept of legal constitutionalization of WTO law where the one of features of legal constitutionalization of WTO is direct effect. Although direct effect is not necessarily relevant feature in domestic constitutionalization, but it may have significance in an international setting. Because direct effect actually involves the integration level such in multilevel judiciary, the utilization by international legal rules of the more binding dispute settlement is available in domestic law. For example, by finding that EU Law had direct effect in the courts of member states, the ECJ both gave EU Law greater binding effect and gave individuals greater control over the development of the EU Law. ${ }^{68}$

Constitutional approach of WTO principally is not merely about building direct effect to the WTO Law, but also concern to the effectiveness of WTO. If domestic court is giving direct effect to WTO Law, thus, the WTO is effective in term of its relation with individual. Furthermore, the domestic court can give a value balance between the right of individual derives from WTO Law and the legislative power.

\section{Conclusion}

Although the WTO Agreements do not mention directly about rights of individuals, but in WTO Panel Report of the case Section 301 - 310 of US Trade Act of 1974 enshrined the relation between individuals and WTO Law through the commitment of their governments. Panel explained that "It would be entirely wrong to consider that

65 Ibid., pp. 1-30. Petersmann's writings on the constitutional functions that trade agreements could serve by limiting governmental discretion to take welfare reducing protectionist measures against the long-term interests of a nation and contrary to individual economic liberty.

66 Ernst Urlich Petersmann, "Rights and Duties of Their Citizens: Towards the 'Constitutionalization' of the Bretton Wood System Fifty Years after its Foundation”, in Beyerlin, U. Bothe et al.,1995, Recht Zwischen Umbruch and Bewahrung: Festschrift fur Rudolf Benhard, Springer Verlag, Berlin/Germany, pp. $1087-1128$.

67 Thomas Cottier and Petros C. Mavroidis, "Concluding Remark", in Cottier, Thomas, and Mavroidis, Petros C., 2003, The Role of the Judge in International Trade Regulation: Experience and Lesson for the WTO, Michigan University Press, Ann Arbor/USA, pp. $349,353$.

68 Joel P. Trachtman, "The Constitutions of the WTO", European Journal of International Law, Vol. 17, No. 3, June 2006, pp. 623-646. 
the position of individuals is of no relevance to the GATT/WTO legal matrix. Many of the benefits to Members which are meant to flow as a result of the acceptance of various disciplines under the GATT/WTO depend on the activity of the individual economic operators in the national and global market places. The purpose of many of these disciplines indeed one of the primary objects of the GATT/WTO as a whole. It is to produce certain market conditions which would allow this individual activity to flourish. Providing security and predictability to the multilateral trading system is another central object and purpose of the system which could be instrumental to achieving the broad objectives of the WTO preamble. The security and predictability in questions are of the multilateral trading system is per force composed not only of states but also, indeed mostly of individual economic operators. The lack of security and predictability affects mostly these individual operators. Trade is conducted most often and increasingly by private operators. It is through improved conditions for these private operators that Members benefit from WTO discipline." ${ }^{69}$

It can be drawn from the Panel report above that the relations between individual and WTO Law is merely depending on whether the government is willing to provide and protect the rights of individual to achieve better benefits from international trading under the WTO Agreements. When the government violates WTO Law which is resulting deprivation of individual's right to achieved better benefits from WTO Agreements, these individuals have inviolable right to obtain judicial protection by relying on WTO Law and DSB Decision. However, the absence of direct effect of WTO law therefore will not create the judicial protection for individuals in a way to give an opportunity for them to rebalance their rights that is impaired by the violation of WTO Law. The absence of domestic judicial protection will also diminish the substantive value of WTO Law where the value of WTO Law will be effectively implied if the national court can relate the individual right and WTO Law by giving direct effect.

In sum, direct effect of WTO Law and DSB Decision is a feasible doctrine that is able to provide judicial protection for any individual who are the victims of WTO violation conducted by their government. Individuals thus are able to rely on WTO Law and DSB Decision in order to challenge the WTO violation that is conducted by their government. By using direct effect doctrine, individuals are able to stand before the court to seek judicial protection in order to rebalance their violated rights. This judicial protection will significantly accommodate rights of individual to achieve better benefit derives from WTO Agreements.

\section{BIBLIOGRAPHY}

\section{A. Books}

Chayes, A, and A.H. Chayes, 1998, The New Sovereignty: Compliance with International Regulatory Agreements, Harvard University Press, Cambridge MA/USA.

Cottier, Thomas, 2007, The Challenge of WTO Law: Collected Essay, Cameron May, London/UK. Denza, Eilleen, 2002, The Intergovernmental Pillars of the European Union, Oxford University Press, Oxford/UK.
Jackson, John H., 1997, The World Trading System, Law and Policy of International Economic System, Second Edition, Massachusetts Institute of Technology Press, Massachusetts/ USA

Jackson, John J., et al., 2002, Legal Problems of International Economic Relations: Cases, Materials, and Text on the National and International Regulation of Transnational Economic Relations, West Publishing Company, NY/USA.

69 WTO Panel Report, Section $301-310$ of US Trade Act of 1974, WT/DS152/R, adopted 27 January 2000, paras. 7.73, $7.75-7$. 
Kuilwijk, Kees Jan, 1996, The European Court of Justice and the GATT Dilemma: Public Interest versus Individual Right, Nexes Edition Academic Publisher, The Netherland.

Malanczuk, Peter, 1997, Akehurts's: Modern Introduction to International Law, Roudledge, London/UK.

Moser, Peter, 1990, The Political Economy of the GATT, Verlag Ruegger, Switzerland.

Nsour, Mohamad F. A., 2010, Rethinking the World Trade Order towards A Better Legal Understanding of the Role of Regionalism in the Multilateral Trade Regime, Sideston Press, Leiden/the Netherland.

Stoll, Peter Tobias and Frank Schorkopf, 2006, Max Planck Commentaries on the World Trade Law, Max Planck Institute for Comparative Law and International Law, MartinusNihoff, Leiden/Netherland.

Thies, Anne, 2013, International Trade Dispute and EU Liability, Cambridge University Press, Cambridge/UK.

Van den Bossche, Peter, 2005, The Law and Policy of the World Trade Organization; Text, Cases and Materials, Cambridge University Press, Cambridge/UK.

Verma, S.K., 2004, An Introduction to Public International Law, Phi Learning Ltd., Delhi/ India.

Weiler, J.H.H., 1999, The Constitution of Europe, Cambridge University Press, UK.

\section{B. Journal Articles}

Alemanno, Alberto, "Judicial Enforcement of the WTO Hormones Ruling Within the European Community: Toward EC Liability for the NonImplementation of WTO Dispute Settlement Decisions?", Harvard International Law Journal, Vol. 45, Issue 2, Summer 2004.

Antoniadis, Antonis, "The European Union and WTO Law: A Nexus of Reactive, Coactive and Proactive Approaches", World Trade Review, Vol. 6, No. 1, 2007.

Barceló III, John J., "The Paradox of Excluding
WTO Direct and Indirect Effect in U.S. Law", Tulane School of Law Journal, 2006.

Brand, Ronal A., "Direct Effect of International Economic Law in the United States and the European Union", Northwestern Journal of International Law \& Business, Vol. 17, Issue 1 Winter, 1997.

Bradley, C.A., "The Charming Betsy Canon and Separation of Powers: Rethinking of the Interpretative Role of International Law", Georgetown Law Journal, Vol. 86, No. 7, 1998.

Cottier, Thomas, and Oesch, Mathias, "WTO Law, Precedents and Legal Change", Turku Law Journal, Vol. 3, No. 1, 2001.

Cottier, Thomas, andK.N.Schefer, "The Relationship between World Trade Organization Law, National Law and Regional Law", Journal of International Economic Law, Vol. 1, Issue 1, 1998,

Davies, Arwel, "Connecting or Compartmentalizing the WTO and United States Legal Systems? The Role of the Charming Betsy Canon", Journal of International Economic Law, Vol. 10, Issue 1, 2007.

Di Gianni, Fabrizio, and Renato Antonini, "DSB Decisions and Direct Effect of WTO Law: Should the EC Courts be more Flexible when the Flexibility of the WTO System has Come to an End?", Journal of World Trade, Vol. 40 No. 4, 2006.

Dunoff, Jeffrey L., "Less than Zero: the Effect of Giving Domestic Effect to WTO Law", Loyola University Chicago International Law Review, Vol. 6, Issue 1, 2008-2009.

Eeckhout, Piet, "The Domestic Legal Status of the WTO Agreement: Interconnecting Legal Systems", Common Market Law Review, Vol. 34, Issue No. 1, 1997.

Daniel Bodansky, "International Decisions", American Journal of International Law, Vol. 100, No. 2, 2006.

Gattinara, Giacomo, "The Relevance of WTO Dispute Settlement Decision in the U.S. 
Legal Order", Legal Issues of Economic Integration, Vol. 36, No. 4, 2009.

Jackson, John H., "The Great 1994 Sovereignty

Debate: United Stated Acceptance and Implementation of the Uruguay Round Results, Chapter 2: Constitutional Question", Columbia Journal of Transnational Law, Vol. 36, No. 7, 1997.

Kuijper, Pieter J., "The Conclusion and Implementation of the Uruguay Round Results by the European Community", European Journal of International Law, Vol. 6, No. 1, 1995.

Petersmann, Ernst-Urlich, "Application of GATT by the Court of Justice of the European Communities", Common Market Law Review, Vol. 20, Issue 3, 1983.

"How to Constitutionalize International Law and Foreign Policy for the Benefit of Civil Society?", Michigan Journal of International Law, Vol. 20, No. 1, 1998.

Schaefer, Matt, "Are Private Remedies in Domestic Courts Essential for International Trade Agreements to Perform Constitutional Functions with Respect to Sub-Federal Governments?", Northwestern Journal of International Law \& Business, Vol. 17, Issue 1, Winter, 1997.

Shell, G. Richard, "Trade Legalism and International Relations Theory: An Analysis of the World Trade Organization", DUKE Law Journal, No. 44, 1995.

Sykes, Alan O., "The Persistent Puzzle of Safeguards: Lessons from the Steel Dispute", Journal of International Economic Law, Vol. 7, Issue 1, 2004.

Tarullo, Daniel, "The Hidden Costs of Dispute Settlement: WTO Review of Domestic AntiDumping Decisions", Law and Policy in International Business, Vol. 34, No. 1, 2002.

Timmermans, Christian, "The EU and Public International Law", European Foreign Affairs Review, Vol. 4, No. 2, 1999.

Trachtman, Joel P., "Bananas, Direct Effect and Compliance", European Journal of International Law, Vol. 10, No. 4, 1999.

Tsymbrivska, Oksana, "WTO DSB Decisions in the EC Legal Order: Approach of the Community Courts", Legal Issues of Economic Integration, Vol. 37, No. 3, 2010.

Tumlir, Jan, "International Economic Order and Democratic Constitutionalism", ORDO Jahrbuch Fur die Ordnung von Wirtschaft und Gesselschaft, Vol. 34, 1983.

\section{Anthology}

Bourgois, J.H.J., "The Uruguay Round of GATT: Some General Comments from an EC standpoint", in Emilou, N. and D. O'Keefe (Eds.), 1996, The European Union and World Trade Law after the GATT Uruguay Round, John Wiley \& Sons, New York/USA.

Cass, Deborah Z., "China and the "Constitutionalization' of International Trade Law", in Deborah Cass, et al. (Eds.), 2003, China and the World Trading System: Entering the New Millennium, Cambridge University Press, Cambridge/UK.

Cottier, Thomas, "A Theory of Direct Effect in Global Law", in Armin Von Bogdany, et al. (Eds.), 2002, European Integration and International Co-ordination Studies in Transnational Economic Law in Honour of Claus-Dieter Ehlermann, Kluwer Law International, the Hague Netherland.

Cottier, Thomas and Petros, C. Mavroidis, "Concluding Remark", in Thomas Cottier and Petros C. Mavroidis (Eds.), 2003, The Role of the Judge in International Trade Regulation: Experience and Lesson for the WTO, Michigan University Press, Ann Arbor/USA.

Cygan, Adam, "The European Court of Justice and External Relations: Internationalist Objectives or Integrationist Policy", in Jen Uwe Wunderlich and David J. Bailey (Eds.), 2011, The European Union and Global Governance: A Handbook, Routledge 
International Handbook- UK.

Dunnof, Jeffrey L., "The Politics of International Constitutions: the Curious Case of the World Trade Organization", in Jeffery L. Dunnof and Joel P. Trachtmann (Eds.), 2009, Ruling the World?: Constitutionalism, International Law, and Global Governance, Cambridge University Press, NY/USA.

Howse, Robert and Kalypso Nicolaidis, "Enhancing WTO Legitimacy Constitutionalization or Global Subsidiarity?", in Robert Howse (Ed.), 2007, The WTO System: Law and Legitimacy, Cameron May Ltd., London/UK.

Klabbers, Jan, "International Law in Community Law: The Law and Politics of Direct Effect", in Piet Eeckhout, et al. (Eds.), 2001-2002, 21 Year Book European Law, Oxford University Press, Oxford/UK.

Petersmann, Ernst-Urlich, "Constitutionalism and WTO: from a State - Centered Approach towards a Human Rights Approach in International Economic", in Daniel L.M. Kennedy and James D. Southwick (Eds.), 2002, The Political Economy of International Trade Law: Essays in Honor of Robert E. Hudec, Cambridge University Press, Cambridge/UK.

Petersmann, Ernst-Urlich, "Multilevel Trade Governance in the WTO Requires Multilevel Constitutionalism", in Joergens C. and Petersmann, Ernst-Urlich (Eds.), 2006, Constitutionalism, Multilevel Trade Governance and Social Regulation, Hart Publising, Oxford/UK.

Petersmann,Ernst-Urlich, "RightsandDuties ofTheir Citizens: Towards the 'Constitutionalization' of the Bretton Wood System Fifty Years after its Foundation", in Bothe Beyerlin,U., et al. (eds.), 1995, Recht Zwischen Umbruch and Bewahrung: Festschrift fur Rudolf Benhard, Springer Verlag, Berlin/Germany.

Von Bogdandy, Armin, "Legal Effect of World Trade Organization Decision within European
Union Law: A Contribution to the Theory of the Legal Acts of International Organizations and the Action for Damages under Article 288 (2) EC", Journal of World Trade, Vol. 39, No. 1, January, 2005.

Von Bogdandy, Armin, "Pluralism, Direct Effect, and the Ultimate Say: On the Relationship between International and Domestic Constitutional Law", International Journal of Constitutional Law (I.CON), Vol. 6, No. 3\&4, 2008.

\section{Cases}

WTO Panel Report, Section 301 - 310 of US Trade Act of 1974, WT/DS152/R, adopted 27 January 2000, paras. 7.73, 7.75 -7.

United States - Sections 301-310 of the Trade Act of 1974, Report of the Panel, WT/DS152/R,22 December 1999, para. 7.72.

Case C-93/02 P, Biret International SA para. 56; Case C-94/02 P, Établissements Biret etCie $S A$ para. 59.

Case C-280/93, Federal Republic of Germany v. Council of the European Union, [1994] ECR I-4973, para. 5073.

Case C-21/72, International Fruit Co. v. Produktschap voor Groenten en Fruit, (1972) ECR 1219.

Case T-174/00, Biret International SA v. Council para.57 (Jan. 11, 2002).

Case T-210/00,ÉtablissementsBiret et Cie SA v. Council para. 64 (Jan. 11, 2002).

Case C-149/96, Portuguese Republic v. Council, 1999 E.C.R. I-8395.

Case T-19/01, Chiquita v. Commission, Judgment of 3 February 2005.

Case C-377/02 Van Parys v Belgische Interventieen Restitutiebureau, Judgment of 1 March 2005.

Joined Cases C--120/06 P and 121/06 P, Fabbricaltaliana Accumulatori Motocarri Montecchio SpA (FIAMM) and Others v. Council and Commission and Giorgio Fedon 
\& Figli SpA and Others v. Council and Commission [2008] ECR I--6513.

Allegheny Ludlum Corp vs. U.S., 367 F. 3d 1339 (Fed. Cir. 2004).

Case Murray vs. Schooner Charming Betsy, 2 Cranch 64, US 64, 2L.Ed. 208 (1804).

United States - Countervailing Measures Concerning Certain Products from the European Communities, WT/DS212/AB/R (9 Dec. 2002).

Opinion of Advocate General Siegbert Alber in Cases C-93/02 P and C-94/02 P, Biret International SA and Etablissements Biret et
Cie. SA v. Council of the European Union, in EU Press Release, CJE/03/39, 15 May 2003. Opinion of Advocate General Poiares Maduro in Joined Cases C--120/06 P and 121/06 P, Fabbricaltaliana Accumulatori Motocarri MontecchioSpA (FIAMM) and Others $v$. Council and Commission and Giorgio Fedon\&FigliSpA and Others v. Council and Commission [2008] ECR I--6513 delivered on 20 February 2008.

The Case 240/83, ADBHU, [1985] ECR 531. 